Ann. Biol. anim. Bioch. Biophys., 1978, 18 (1), 11-19.

\title{
The nature of somatomedins and related peptides
}

\author{
par J. L. VAN DEN BRANDE, Sylvia VAN BUUL
}

Department of pediatrics, Erasmus University of Rofterdam, the Netherlands.

\begin{abstract}
Summary. Somatomedins are growth hormone-dependent plasma factors stimulating sulfation of chondroitin in cartilage, and perhaps exerting other stimulatory functions in the growth of supporting tissues. They are most probably secreted by the liver and appear in plasma as macromolecules. Their synthesis appears to be limited by the protein synthetic capacity of the liver. After acidification of plasma, small peptides with somatomedin activity are released most probably from specific carrier proteins. Varying schemes of isolation and bioassay techniques have led to the identification of a number of such small peptides having different chemical characteristics but appearing to be in competition for the same or closely related receptors in human placental cell membranes.

The quantitative importance of the small SM's while bound to carrier in the native state is still uncertain. The hypothesis that somatomedin is the mediator of the growth promoting effect of $\mathrm{GH}$ is still uncertain, but no available information today has disproven it. The alternative hypothesis that GH acts directly on the growth of the liver, which in furn secretes SM in order to harmonize its growth with that of other tissues, in particular the supporting tissues, is attractive and is equally compatible with the data at hand.
\end{abstract}

\section{Introduction.}

Over the years many unifying theories have been proposed attempting to explain the mechanism of growth regulation. The disputes regarding the importance of function as opposed to genetic information in regulating the mass of organs or tissues have not completely ceased. Nevertheless much of the interest has shifted from this general approach to the more specific question of which substances carry the growth regulating messages. The recent availability of powerful means for separating proteins has allowed investigators to isolate and characterize growth regulatory peptides from humoral fluids.

This review summarizes the present knowledge regarding the source and nature of the somatomedins (SM), peptides which are supposed to be involved in the regulation of cartilage growth. Their relationship with some other growth regulatory peptides will also be discussed. 


\section{Somatomedin. Definition.}

According to the hypothesis of Salmon and Daughaday (1957), a number of the anabolic effects of growth hormone $(\mathrm{GH})$ are not direct, but are brought about by intermediate serum substances. The mediators which stimulate sulfate uptake into chondroitine sulfate of cartilage in vitro are termed somatomedins (Daughaday et al., 1972). Plasma extracts which contain somatomedin (i.e. are stimulatory in the cartilage bioassay) have been shown to be stimulatory in a wide variety of other biological systems such as those which measure protein RNA and DNA synthesis in cartilage, aminoacid transport and protein synthesis in muscle, glucose utilisation and suppression of lypolysis in fat (for reviews see Van Wyk ef al., 1974 ; Froesch ef al., 1975 ; Daughaday, Herington and Phillips, 1975a ; Hall and Luft, 1974). Since practically all such studies have been done with crude plasma extracts it is impossible at present to conclude which of the phenomena are caused by somatomedins in the mixtures or by other peptides.

\section{Somatomedin activity in human plasma under different conditions.}

While attempts were being made to extract somatomedins from plasma for chemical characterization, a number of investigators worked at improving the assay method. This resulted in the development of a series of methods which have higher precision and/or are easier to perform than the original hypophysectomized rat assay (Salmon and Daughaday, 1957). Amongst these are the bioassays using normal costal cartilage from fasted rats, rabbits and pigs and the pelvic rudiments of chick embryo (Yde, 1968 ; Bala, Hankins and Smith, 1975 ; Van den Brande and Du Caju, 1974a ; Hall, 1970). The availability of highly purified somatomedins has encouraged the development of radioreceptor assay systems using different tissues as source of SM-receptors : human placental cell membranes for SM-A (Takano ef al., 1975) and SM-C (Van Wyk et al., 1975), and rat liver cell membranes (Megeysi ef al., 1975a) and fibroblasts (Zapf, Waldvogel and Froesch, 1975) for NSILA-S. Recently Van Wyk ef al. (1976) have reported success in raising antibodies to SM-C ; this allowed them to develop a radioimmunoassay (RIA). Similarly Reber and Liske (1976) have described a RIA for NSILA-S.

Such techniques have permitted a more accurate measurement of SM-activity in plasma in different clinical conditions. We have recently summarized the studies reported in this area (Van den Brande, 1976).

Throughout those studies $\mathrm{GH}$ remained the overall controller of SM-activity. It was low in hypopituitarism and was restored during $\mathrm{GH}$-therapy. It has also been found to be low in short stature associated with emotional deprivation (in a number of the cases associated with low $\mathrm{GH}$ secretion) and returns to normal during catch-up growth after removal of the child from its poor environment. In acromegaly most bioassay systems as well as the radioreceptor and radioimmuno assays demonstrate high values. In a number of conditions low SM had been found in the presence of normal growth hormone. Amongst these are cerebral gigantism, liver insufficiency, kidney failure and malnutrition. While in the latter two there is some indication of 
the presence of material inhibiting the expression of SM-activity in the bioassay, the former two more probably are the consequence of respectively an adaptive change and a limitation in the capacity to produce somatomedin. Some other hormones than growth hormone also appear to have an influence on apparent SM-activity as measured in the bioassay. This is not always an effect on SM-production in vivo but may also be a direct effect of the hormone on the cartilage in vitro. The latter appears to be the case with thyroid hormones which have a direct stimulatory effect on the sulfation in most bioassay systems. Cortisone, which depresses the SM-activity, appears to act both directly on the cartilage and on SM-production. While testosterone does not seem to have an influence, estradiol in high doses lowers SM-activity in plasma most probably as a consequence of diminished SM-production. A stimulatory effect of insulin on SM-production is compatible with the normal SM-activity in plasma of children with obesity and some patients with craniopharyngioma, who exhibit a normal growth rate in spite of low plasma GH and usually have high insulin levels.

Besides being subjected to hormonal influences and changes in pathological conditions SM-activity varies with age and size of the individual. There is a gradual change with age ; it is low at birth and increases gradually until adult levels are reached at age six. This had been suspected from early studies and has now been well documented. Since it has been demonstrated in rabbits (Beaton, 1976) and rats (Heinz, Garland and Daughaday, 1970) that cartilage sensitivity is much higher in the young organism, it is conceivable that such low levels are sufficient for obtaining the observed high growth rate in small children as well.

Another variable, which influences SM-levels, and as far as we know again not related to changes of $\mathrm{GH}$-secretion, is the difference in height reached by children of comparable developmental age. When SM-activity is related to standard deviation score for height a reasonable correlation is found. Both the age-dependent change of SM and the variation with height, independent of age, may be the expression of one common variable, namely, absolute height, which yields the highest correlation with plasma SM-activity $(r=.80)$.

\section{Relationship of liver size and function and plasma SM-activity.}

Although liver, kidney and muscle all have been shown to release SM-like material most evidence points to the liver as the main producer of SM (McConaghey, 1972 ; Daughaday, Phillips and Herington, $1975 b$ and others). Such a conclusion is supported by the growth hormone-dependent release of SM-like material by the perfused liver, the fall of plasma SM-activity after partial hepatectomy and its gradual restoration during regeneration, the low SM-levels in patients with insufficiency of the liver and the in vitro production of SM-like material by isolated rat liver cells. Some years ago we have suggested that the liver might act as the organ controlling SM-levels in plasma, thus insuring growth of supporting tissues in harmony with its own (and perhaps that of other) important parenchymatous tissues (Van den Brande and Du Caju, 1974b). The data which have recently become available on plasma levels in different conditions further support this view. The relationship of SM with height irrespective of age also fits with this argument. Indeed, there is a strict linear rela- 
tionship between height and liver size. As a consequence of this, SM correlates equally well with either of these two parameters.

Since it is very possible that at least part of plasma SM is of small molecular size and carried by large proteins (see below) (Salmon and Daughaday, 1958 ; Bala, Blakeley and Smith, 1976 ; Zapf, Waldvogel and Froesch, 1975), and since the site of production of such proteins is most likely the liver, it is concievable that the production of this carrier protein is determined in some way by the functioning mass of the liver. By virtue of its protecting effect on the destruction of small SM, it might be the limiting factor determining actual SM-levels. This reasoning does not necessarily imply, nor does it exclude, that the small SM-peptides are synthesized in the liver. The same reasoning would apply if in addition there exists a non-dissociable large SM (see below) produced by the liver, the production of which again may be linked to the protein synthetic capacity of that organ.

The known overall effects of hormones on protein synthesis in the liver also fit into this concept. It is stimulated by growth hormone and insulin, and is inhibited by glucocorticoids and high doses of estrogens. This is quite in line with the SM-activity as found in $\mathrm{GH}$ deficiency, patients with hyperinsulism and low $\mathrm{GH}$, hypercorticism and patients treated with high doses of estrogens. GH should then have a more preferential influence on SM and/or its carrier.

\section{Nature of plasma somatomedin.}

For many years investigators have attempted to isolate the active molecule from plasma. In native human and rat plasma, somatomedin resides in the macromolecular fraction (Daughaday and Kipnis, 1966 ; Bala, Ferguson and Beck, 1970 ; Van den Brande ef al., 1971 and others). After exposure of plasma or Cohn fraction IV to acid at $\mathrm{pH} 2$, the somatomedin activity is found in a fraction with a molecular weight between 6 and $7 \times 10^{3}$ daltons. Recent evidence supports the notion that this is the consequence of dissociation from carrier proteins of large molecular size (Van Wyk, Hall and Weaver, 1969 ; Hintz, Orsini and Van Camp, 1974 ; Megeysi et al., 1975b).

Further separation of the small peptides has yielded a series of peptides with somatomedin activity. Isolation of SM A1 and A2 has been monitored by the chick embryo cartilage assay of Hall (1970). They are neutral peptides of approximately $7000 \mathrm{MW}$ and of known aminoacid composition. SM-A1 and A2 are very similar, and in fact one may be derived from the other during the isolation procedures (Fryklund, Uthne and Sievertsson, 1974). SM-B, an acid peptide, is quite different since is it not active on cartilage but on human glia-like cells in culture (Uthne, 1973). Its aminoacid composition is also known (Fryklund ef al., 1974). SM-C has been isolated by van Wyk ef al. (1974) using the hypophysectomized rat asay. It is an alkaline peptide of unknown aminoacid composition. To our own SM-preparation, we have given the operational term SM-P ( $P$ for porcine bioassay used to monitor its isolation) (Van den Brande and van Buul, 1975). It has not yet been obtained in pure form.

Another one is NSILA-S (Oelz et al., 1972 ; Rinderknecht and Humbel, 1976a) the small molecular fraction which cannot be suppressed by insuline antibodies. Studies with this peptide have primarily been directed towards its insulin-like effects. Recently however its similarity, especially with SM-C, has been recognized ; studies in carti- 
lage have demonstrated that it is very potent in the hypox rat assay in stimulating sulfate incorporation (Zingg and Froesch, 1973) and also on DNA-synthesis in fibroblasts (Rechler ef al., 1974). Studies in vivo with NSILA-S have not been directed towards growth promotion but it has been demonstrated that is has a strong and somewhat prolonged insulin-like effect. Recently, Rinderknecht and Humbel (1976b) have published the aminoacid composition and the sequence of 31 aminoacids at the aminoterminal end of the molecule. It is quite homologous to the $B$ chain of insulin.

Closing this list is MSA, the multiplication-stimulating activity (Dulak and Temin, 1973). This material, isolated from fetal calf serum and from the medium of liver cell cultures, was primarily isolated for its growth-promoting effect on fibroblasts, but again it has been shown to be stimulatory in the somatomedin rat bioassay.

All these peptides or fractions, with the exception of $S M-B$, are active on cartilage and all but MSA have been demonstrated to be GH-dependent (Cohen, Short and Nissley, 1975 ; Smith and Temin, 1974). Hence most of them are candidates for the role which Daughaday et al. have tentatively assigned to somatomedin.

Little is known at present about the nature and physiology of the large molecular $S M$ in native plasma. It is suggested by the data of Hintz, Orsini and Van Camp (1974) on SM-C that these large molecules are carrier proteins having specific binding characteristics for SM. A similar situation has been demonstrated with NSILA-S and MSA (Zapf, Waldvogel and Froesch, 1975 ; Zapf et al., 1977 ; Cohen and Nissley, 1976). Such carrier binding could have a protecting role against the degradating effect of proteinases. This is supported by the difference in half life time of large molecular SM (2-4 hrs) and small SM ( $\pm 8 \mathrm{~min}$.) (Cohen and Nissley, 1976). It remains uncertain if the small carrier bound SM'S represent all SM in native plasma. Poffenbarger (1975) recently isolated a large NSILA molecule which is not dissociable. While the material which he has isolated does not have SM-activity and is only insulin-like it has not been ruled out that a similar situation may exist with regard to SM. The overwhelming losses of SM-activity in the first steps of isolation certainly leave room for such a possibility.

\section{Interrelationship of the somatomedins with regard to their affinity for bin- ding to human placental cell membrane receptors.}

In spite of differences in charge and aminoacid composition the SM-like substances isolated thus far show quite similar biological actions in vitro. This raises the question of a possible similarity of these peptides. Information on their individual effects on tissues and their interplay can be obtained by studying their behaviour in the different in vitro systems. Such comparisons have barely been made. Receptor studies offer the possibility to obtain more insight in the receptor populations involved in the interaction of the somatomedins with the target organs. We have attempled to obtain information on the interrelationship of insulin, NSILA-S and SMs by studying their behaviour in the placental cell membrane system, using insulin, NSILA-S, SM-A and SM-C as label (van Buul and Van den Brande, submitted for publication). We found that all labeled SM-like substances appear to bind to closely related if not identical receptor populations, which are extremely sensitive to very low concentrations of SM-like 
material and insensitive to insulin. This in contrast with labeled insulin which binds to a different receptor population, sensitive to both insulin and SM in physiological concentrations (Froesch et al., 1975 ; Takano ef al., 1975 ; Van Wyk ef al., 1975).

\section{Relation of somatomedin to insulin and "insulin-like " factors possessing no sulfation stimulating activity.}

Besides somatomedins, a number of other growth factors such as insulin, nerve growth factor, epidermal growth factor, fibroblast growth factor, have been isolated. They all appear to induce a set of biochemical effects at the cellular level which as a whole can be indicated as a positive pleiotypic response. They stimulate aminoacid transport, protein synthesis, RNA and DNA synthesis and promote cell division. Insulin is the prototype of such a substance, hence the name « insulin-like » was given to this whole group of substances. At the physiological level they have quite divergent effects.

Whereas it certainly makes sense to group these substances under the definition of « insulin-like », it is premature at this moment to imply that the somatomedins are insulinlike in a physiological sense, namely promoting glucose consumption and lipid synthesis and inhibiting lipolysis. Evidence for such behaviour has been obtained with impure mixtures of small molecular SM. It is quite possible that the isolation procedures yield a heterogeneous mixture of peptides, some of which are physiologically more similar to insulin and others which have more distinct or even exclusive SM-characteristics.

Moreover the behaviour of the native large molecular form of SM has not been studied in this respect. Only the further study of this form of somatomedin will yield more insight into its possible physiological role.

Réunion Groupe Développement INRA/Productions animales Montpellier, 17-18 mai 1977.

Acknowledgment. - Thanks is due to Mrs. M. de Bruijne for preparing the manuscript. Studies by the authors, mentioned in this paper were supported in part by FUNGO

Résumé. Les somatomédines représentent un groupe de facteurs plasmatiques stimulant la sulfatation de la chondroîtine du tissu cartilagineux et ayant probablement un effet stimulateur sur la croissance d'autres tissus. La sécrétion se fait probablement dans le foie et la somatomédine apparaît dans le sang sous forme de macromolécule. La synthèse semble être limitée par la capacité du foie à produire des protéines.

L'acidification du plasma provoque l'apparition de petits peptides ayant une activité somatomédine et qui seraient probablement libérés d'une ou plusieurs protéines porteuses.

Des schémas différents d'isolement et l'utilisation de différents « bio-assays » ont abouti à l'identification de plusieurs somatomédines possédant des caractéristiques chimiques variables, mais qui semblent se lier à la même population de récepteurs membranaires de cellules de placentas humains. L'importance quantitative des somatomédines de poids moléculaires bas, liées aux protéines porteuses, n'est pas bien connue. L'hypothèse selon laquelle la somatomédine serait le médiateur de l'effet de l'hormone somatotrope sur la croissance n'a pas encore été prouvée, sans qu'il y ait d'arguments contre. Par ail- 
leurs, on pense que l'hormone de croissance pourrait agir directement sur le foie qui sécrèterait à son tour la somatomédine. Cette dernière exercerait son effet sur la croissance des tissus en général et en particulier sur le tissu conjonctif. La bonne corrélation qui existe entre la taille de l'individu ef celle de son foie rend cette hypothèse séduisante et compatible avec les faits connus.

\section{References}

BALA R. M., HANKINS C., SMITH G. R., 1975. A somatomedin assay using normal rabbit cartilage in clinical studies. Can J. Physiol. Pharmac., 53, 403-409.

BALA R. M., BLAKELEY E. D., SMITH G. R., 1976. Size heterogeneity of human serum somatomedin. J. clin. Endocr. Metab., 43, 1110-1121.

BALA R. M., FERGUSON K. A., BECK J. S., 1970. Plasma biological and immunoreactive human growth hormone-like activity. Endocrinology, 87, 506-516.

BEATON G. R., 1976. Studies on serum somatomedin activity and cartilage responsiveness in the regulation of growth. Thesis, Fac. Sci., Univ. Witwatersrand, Johannesburg.

BUUL S. VAN, VAN DEN BRANDE J. L., Binding of somatomedin-A, Somatomedin-C, Non-suppressible insulin-like activity (NSILA-S) and insulin to human placental cellmembranes (Submitted for publication).

COHEN K. L., NISSLEY S. P., 1976. The serum half-ife of somatomedin activity : evidence for growth hormone dependence. Acta endocr. (Kbh), 83, 243-258.

COHEN K. L., SHORT P. A., NISSLEY S. P., 1975. Growth-hormone dependent serum stimulation of DNA synthesis in chick embryo fibroblasts in culture. Endocrinology, 96, 193-198.

DAUGHADAY W. H., HALL K., RABEN M., SALMON Jr. W. D., VAN DEN BRANDE J. L., VAN WYK J. J., 1972. Somatomedin : proposed designation for sulphation factor. Nature (London), 235, 107.

DAUGHADAY W. H., HERINGTON A. C., PHILLIPS L. S., 1975a. The regulation of growth by endocrines. Ann. Rev. Physiol., 37, 211-244.

DAUGHADAY W. H., KIPNIS D. M., 1966. The growth promoting and anti insulin actions of somatotropin. Recent Progr. Horm. Res., 22, 49-99.

DAUGHADAY W. H., PHILliPS L. S., HERINGTON A. C., 1975b. Somatomedin generation by perfused livers. Adv. Metab. Disord., 8, 151-157.

DULAK N. C., TEMIN H. M., 1973. A partially purified polypeptide fraction from rat liver cell conditioned medium with multiplication-stimulating activity for embryo fibroblasts. J. Cell. Physiol., 81, 153-160.

FRYKLUND L., UTHNE K. SIEVERTSSON H., 1974. Identification of two somatomedin A active polypeptides and in vivo effects of a somatomedin A concentrate. Biochem. biophys. Res. Comm., 61, 957-962.

FRYKLUND L., UTHNE K., SIEVERTSSON H., WESTERMARK B., 1974. Isolation and characterization of polypeptides from human plasma : enhancing the growth of human normal cells in culture. Biochem. biophys. Res. Comm., 61, 950-956.

FROESCH E. R., SCHLUMPF U., HEIMANN R., ZAPF J., HUMBEL R. E., RITSCHARD W. J., 1975. Purification procedures for NSILA-S, Adv. Mefab. Disord., 8, 203, 211, 237.

HALL K., 1970. Quantitative determination of the sulfation factor activity in human serum. Acta endocr. $(K b h), 63,338-350$.

HALL K., LUFT R., 1974. Growth Hormone and somatomedin. Adv. Metab. Disord., 7, 1-36.

HEINZ J. N., GARLAND J. T., DAUGHADAY W. H., 1970. Incorporation of ${ }^{35}$ S-sulfate into rat cartilage explants in vitro : effects of aging on responsiveness to stimulation by sulfation factor. Endocrinology, 87, 688-692.

HINTZ R. L., ORSINI E. M., VAN CAMP M. G., 1974. Evidence for a somatomedin binding protein in plasma. 56th annu. Meet. The Endocrine Society, June 12, (Abstract-31).

McCONAGHEY P., 1972. The production of « sulphation factor " by rat liver. J. Endocr., 52, 1-9.

MEGEYSI K., KAHN C. R., ROTH J., NEVILL D. M., NISSLEY S. P. HUMBEL R. E., FROESCH E. R., 1975a. NSILA-S receptor in liver plasma membranes characterization and comparison with insulin receptor. J. biol. Chem., 250, 8990-8996. 
MEGEYSI K., KAHN C. R., ROTH J., GORDEN P., 1975b. Circulating NSILA-S in man : Preliminary studies of stimuli in vivo and of binding to plasma components. J. clin. Endocr., 41, 475-484.

OELZ O., FROESCH E. R., BUNZLI H. F., HUMBEL R. E., RITSCHARD W. J., 1972. Antibodysuppressible and nonsuppressible insulin-like activities, 685-701. In GREEP R. O., ASTWOOD E. B., Handbook of physiology, Sect. 7, Endocrinology l.

POFFENBARGER P. L., 1975. The purification and partial characterization of an insulin-like protein from human serum. J. clin. Invest., 56, 1455-1463.

REBER K., LISKE R., 1976. Radioimmunoassay for non-suppressible insulin-like activity. Horm. Res., 7, 201-213.

RECHLER M. M., PODSTALNY J. M., GOLDFIN I. D., WELTS C. A., 1974. DNA-synthesis in human fibroblasts : stimulation by insulin and by non suppressible insulin-like activity (NSILA-S). J. clin. Endocr. Metab., 39, 512-521.

RINDERKNECHT E., HUMBEL R. E., 1976a. Polypeptides with nen-suppressible insulin-like and cell-growth promoting activities in human serum : isolation, chemical characterization and some biological properties of forms I and II. Proc. nat. Acad. Sci., 73, 2365-2369.

RINDERKNECHT E., HUMBEL R. E., 1976b. Amino-terminal sequences of two polypeptides from human serum with non suppressible insulin-like and cell-growth promoting activities. Evidence for structural homology with insulin B chain. Proc. nat. Acad. Sci., 73, 4379-4381.

SALMON W. D. Jr., DAUGHADAY W. H., 1957. A hormonally controlled serum factor which stimulates sulfate incorporation by cartilage in vitro. J. Lab. clin. Med., 49, 825-836.

SALMON W. D. Jr., DAUGHADAY W. H., 1958. The importance of amino-acids as dialyzable components of rat serum which promole sulfate uptake by cartilage from hypophysectomized rats in vitro. J. Lab. clin. Med., 51, 167-173.

SMITH G. L., TEMIN H. M., 1974. Purified multiplication-stimulating activity from rat liver cell conditioned medium : comparison of biological activities with calf serum, insulin and soma tomedin. J. Cell. Physiol., 84, 181-192.

TAK ANO K., HALL K., FRYKLUND L., HOLMGREN A., SIEVERTSSON H., UTHNE K., 1975 . The binding of insulin and somatomedin $A$ to human placental membrane. Acta Endocr (Kbh), 80, 14-31.

UTHNE K., 1973. Human somatomedins purification and some studies on their biological actions. Acta Endocr. (Kbh), 73, suppl. 175.

VAN DEN BRANDE J. L., 1976. Plasma somatomedin. Clinical observations, 271-285. In PÉCILE A., MÜLLER E. E., Growth hormone and related peptides, Excerpta med. Int. Congr. Ser., $n^{\circ} 381$. Amsterdam.

VAN DEN BRANDE J. L., DU CAJU M. V. L., 1974a. An improved technique for measuring somatomedin activity in vitro. Acta Endocr. (Kbh), 75, 233-242.

VAN DEN BRANDE J. L., DU CAJU M. V. L., 1974b. Plasma somatomedin activity in children with growth disturbances, 98-115. In RAITI S., Advances in human growth hormone research. DHEW Publ. no 74-612, U. S. Govt. Printing Office, Washington, D. C.

VAN DEN BRANDE J. L., VAN BUUL S., 1975. Somatomedins. Israel J. med. Sci., 11, 693-698.

VAN DEN BRANDE J. L., VAN WYK J. J., WEAVER R. P., MAYBERRY H. E., 1971. Partial characterization of sulfation and thymidine factors in acromegalic plasma. Acta Endocr. $(K b h),$.66 , 65-81.

VAN WYK I.J., FURLANETTO R. W., UNDERWOOD L. E., D'ERCOLE A. J., DECEDIE C. J., 1976. Characterization of somatomedin-C in human serum. 5th int. Congr. Endocr., Hamburg, Fed. Rep. Germany, July 18-24, 1976.

VAN WYK J. J., HALL K., WEAVER R. P., 1969. Partial purification of sulphation factor and thymidine factor from plasma. Biochim. biophys. Acta, 192, 560-562.

VAN WYK J. J., UNDERWOOD L. E., BASEMAN J. B., HINTZ R. L., CLEMMONS D. R., MARSHALL R. N., 1975. Explorations of the insulin-like and growth promoting properties of somatomedin by membrane receptor assays. Adv. Metab. Disord., 8, 127-150.

VAN WYK J. J., UNDERWOOD L. E., HINTZ R. L., CLEMMONS D. R., VOINA S. J., WEAVER R. P., 1974. The somatomedins : a family of insulin-like hormones under growth hormone control, 259-310. In GREEP R. O., Recent Progr. Horm. Res., 30, Acad. Press, New York, N. Y.

YDE H., 1968. A simplified technique for the determination of growth hormone dependent sulfation factor using infact animals. Acto endocr. (Kbh), 57, 557-564. 
ZAPF J., WALDVOGEL M., FROESCH E. R., 1975. Binding of non-suppressible insulin-like activity to human serum. Evidence for a carrier protein. Arch. Biochem., 168, 638-645.

ZAPF J., KAUFMANN U., EIGENMANN E. J., FROESCH E. R., 1977. Determination of non-suppressible insulin-like activity in human serum by a sensitive protein-binding assay. Clin. Chem., 23, 677-682.

ZINGG A. E., FROESCH E. R., 1973. Effects of partiolly purified preparations with non-suppressible insulin-like activity (NSILA-S) on sulfate incorporation into rat and chicken cartilage. Diabetologica, 9, 472-476. 